\title{
Non-Price Determinants of Automotive Demand: Restyling Matters Most
}

\author{
Oleg Korenok, George E. Hoffer, and Edward L. Millner* \\ Virginia Commonwealth University
}

September 8, 2009

\begin{abstract}
This paper analyzes market share changes in automobile and light truck submarkets. We find that new product, as measured by restyling, represents the most consistent, dominant determinant of demand. On average a ten percent reduction in relative price would yield only one-tenth the market share impact of a restyling. Alternatively, one would have to double one's relative advertising expenditures to match the impact of a restyling. Several demand determinants not previously modeled, including rebranding and warranty curtailments, were detrimental to domestic manufacturer market shares. Safety appliance adoptions and changes in vehicle reliability had minimal impact on demand.
\end{abstract}

Keywords: automobile pricing, warranty, safety appliances, rebranding, reliability JEL classification: L62, L11, L15, M31, M37

\footnotetext{
* Corresponding author: Oleg Korenok, School of Business, 301 W. Main Street, Richmond, VA, 23284-4000, phone: (804) 828 3185, e-mail: okorenok@vcu.edu.
} 


\section{Introduction}

Since 1996, the market share of domestic automotive producers has continued its secular decline falling from 72.9\% in 1996 to $47.4 \%$ in 2008 (Automotive News, 1997, 2009). Several researchers have found that new product introduction affects significantly the market shares and financials of automotive producers. Notable is the work of Pauwels, Silva-Risso, Srinivasan, and Hanssens (2004). They investigated the impact that new product introductions and promotional incentives had on profits, total revenues, and market valuations of automotive firms. While concluding that new product trumped incentives as a stimulant, they suggested several avenues for further research. It is the purpose of this paper to extend their work in three important dimensions suggested by them.

First, Pauwels et al. note that their data period “ ... covers only a fraction of the history of the automobile industry...” (p. 154). The time period of the present study more than doubles the model years observed. Expanding the data set through the 2006 model year is significant because the expanded time frame encompasses a period of major product and non-product innovation. Two examples of the latter include the introduction of decade-long powertrain warranties and $0 \%$ subvented financing for up to 60 months. An example of major product innovation captured in the present paper is inclusion of the 'crossover', a segment whose 2009 market share exceeds that of all truck- based SUV categories combined (Automotive News, 2009).

Second, they leave “... explanations of differences and effects across firms and categories for further studies.” (p154). The present study analyzes the impact of 10 price and non- price determinants of demand by market class, by manufacturer, and by country of origin. Finally, they suggest that “... researchers might investigate consumer acceptance ratings that are available before launch...” that “... may help predict the performance impact of specific introductions.” (p.154). The present paper addresses this issue by including consumer generated measures of vehicle quality and reliability which may influence market responses to new automotive product.

In addition, this paper extends the work of Pauwels et al. by decomposing the effects of several variables that change simultaneously with product innovations. Most importantly, a significant increase in advertising expenditures virtually always accompanies new product 
introduction (Delre et al., 2007). In our data set, model year advertising expenditures almost double when firms introduce new products. For instance, in the large car segment, when Chrysler replaced the Concorde with the Chrysler 300 for the 2005 model year, advertising expenditures on Chrysler's large car entry increased by $400 \%$. Without advertising as an independent variable, one cannot ascertain whether the sevenfold increase in Chrysler's unit sales between model years is a result of the new product introduction or increased advertising expenditures. Finally, this paper incorporates several variables, e.g., vehicle line rebranding and changes in warranty terms, which previous studies omitted in modeling automotive market demand.

After controlling for a wide array of determinants of demand, we find that new product introduction has a major impact on demand. From 1995 through 2006, restyling cycles averaged one year longer for domestic manufacturers then for foreign firms. This difference in styling activity better explains the 25.5 percent market share loss of domestic manufacturers over this period than more often cited factors such as reliability differentials as cited by Consumer Reports. Interestingly, we find that warranty curtailments and vehicle line name changes, factors omitted in previous studies, importantly decrease demand for domestic manufacturers.

The paper has five more sections. Section 2 cites previous work in this area and provides a description of the model. Section 3 contains a statement of our hypotheses and justifications for them. Section 4 provides a brief summary of the data. Section 5 reports the results. Section 6 concludes.

\section{Automotive Demand}

A large number of variables influence model year unit sales for a vehicle. We divide them into two groups: factors that we measure directly and those for which we control indirectly. The first group includes the relative price of the model and non-price determinants of demand: relative advertising, restyling, change of the model name, warranty, safety, quality/reliability, several forms of temporary price reductions, the number of competitors, and length of the model year. We control indirectly for macroeconomic conditions and market history. We summarize the demand for a vehicle as

$$
Q_{i, t}=f\left(P_{i, t}, A_{i, t}, R S_{i, t}, N C H_{i, t}, W_{i, t}, S_{i, t}, Q R_{i, t-1}, I_{i, t}, R_{i, t}, C O M_{i, t}, L E N_{i, t} ; P_{-i, t}, A_{-i, t}, M_{t}, M S T_{i t}\right),
$$


where $i=1, \ldots, N$ denotes models, $t=1, \ldots, T$ denotes model years, $Q_{i, t}$ denotes sales in a model year, $P_{i, t}$ denotes model year price of a vehicle while $P_{-i, t}$ denotes competitors' prices, $A_{i, t}$ denotes advertising while $A_{-i, t}$ denotes competitors' advertising, $R S_{i, t}$ denotes styling, $N C H_{i t}$ denotes a vehicle line’s name, $W_{i, t}$ denotes warranty, $S_{i t}$ denotes safety appliance, $Q R_{i, t-1}$ denotes observed relative quality/reliability with one year delay, $I_{i t}$ denotes interest subvention, $R_{i t}$ denotes manufacturer cash incentives, $L E N_{i t}$ denotes model year length, $C O M_{i t}$ denotes number of competitors, $M_{t}$ denotes macroeconomic conditions that are common across the models, and $M S T_{i, t}$ denotes market structure factors.

\subsection{Research Hypotheses}

The introduction of new product in a timely manner is a crucial component of maintaining competitive advantage (Carbonell and Rodriquez, 2006; Chang and Cho, 2008). We hypothesize that a styling change has a positive impact on demand and that the size of the impact increases with the extent of the styling change. The assumption that consumers desire innovation implies that the demand for restyled vehicles is higher. Previous studies by Kwoka (1993), Sherman and Hoffer (1971), Hoffer and Reilly (1984), Millner and Hoffer (1993), Purohit (1992), Berry, Levinson, and Pakes (1995), and more recently Nakata, Im, Park, and Ha (2006), as well as Train and Winston (2007) find evidence consistent with the positive impact of restyling on demand.

We hypothesize that a name change has a positive effect on demand. If the current name equity is high, a name change is unlikely. If the current name capital is low, we expect a higher chance of a name change with a positive impact on demand. However, a name change raises another hurdle for the new model introduction. Not only must manufacturers educate consumers on the new vehicle's attributes, but also what position the vehicle line takes among the make's model offerings.

We anticipate warranty improvement to have a positive effect on demand, while warranty curtailment to have a negative effect. Warranty improvements are a signal of improved vehicle quality and of lower maintenance costs. Warranty curtailments are just the opposite. 
We expect the relationships between demand and changes in safety appliances to be ambiguous. On one hand, since higher safety levels are desirable, e.g., Boulding and Purohit (1996), we expect a positive relationship between market share and changes in levels of safety equipment. On the other hand, if the increase in price associated with added appliances exceeds the additional benefit, then vehicles with the appliances would be less desirable than their lessequipped competitors. The relationship may differ by subclass. In the more expensive subclasses the same safety appliance will have a smaller percentage impact on price than in less expensive subclasses. Recently, Pruitt and Hoffer (2004) could find no evidence that structural improvements, as reflected in better Insurance Institute for Highway Safety televised frontal crash test results, impacted market shares. Others (see Reilly and Hoffer[1983]) have consistently found little adverse sales impact from NHTSA-influenced recall campaigns.

All else equal, consumers prefer higher quality, as measured by greater reliability. We expect our quality/reliability measure to move together with demand. We lag the quality measure because quantifiable information is generally not available until the subsequent model year. Sullivan (1998) concluded that the higher perceived quality of imported automobile brands, as measured by Consumer Union’s (CU) “Trouble Index”, translated into higher used vehicle N.A.D.A. book values than domestic branded twins.

We include interest subventions and rebates in two ways. First, we measure price net of interest subventions and rebates. Therefore, price captures any stimulus that incentives generate by reducing the effective price faced by consumers. We also include measures of these two incentives directly as independent variables, to capture any impact that they might have independent of their effect on net price.

The relationships between interest subventions, manufacturer cash incentives and demand, holding net price constant, are ambiguous. On one hand, the effects would be positive if consumers view interest subventions and cash incentives as temporary price reductions. On the other hand, dealers might not pass forward the full incentive value, mitigating the effect. Busse, et al (2006), using J.D. Power PIN data, estimated that dealers passed on to the consumer only 30- 40 percent of the dollar value of manufacturer-to-dealer incentives. This compared to an estimated 70-90 percent pass through when manufacturers used direct consumer incentives.

We hypothesize that own advertising has a positive impact on demand, while competitor's advertising has a negative impact. A profit maximizing manufacturer will increase 
advertising only when it stimulates demand. Kwoka (1993) found own advertising to be a significant demand determinant. Given the rivalrous nature of the industry, we anticipate that the majority of sales increases for the promoted model will be at the competitor's expense. Indeed Kwoka (1993) reports that competitor advertising levels have an adverse impact on own sales.

We hypothesize that own price has a negative impact on sales while competitors' prices have a positive impact. The law of demand justifies our hypotheses about the effect of changes in own price. We expect competitors' prices to vary directly with sales since this is an increase in the price of substitutes. McCarthy (1996) estimates a -0.87 the price elasticity of demand for automobiles in the U S market.

To control the idiosyncratic effects of early or delayed model year introductions, we include the number of quarters in a given model year as an independent variable. Most model years cover a four-quarter period spanning two calendar years. However, model years can last a little as three quarters and as long as six quarters. Take Jeep, for example. The 1997 and 2006 model year Cherokee and Commander, respectively, had three-quarter runs, while the 1996 Cherokee had a five-quarter run and the 2004 Grand Cherokee had a six-quarter run.

Finally, we measure entry and exit. As noted below, the dependent variable is market share growth. Therefore, we control for the number of competitors within a submarket. It is more difficult to increase market share when entry is occurring and easier when exit occurs.

\subsection{Indirect Controls}

We control for macroeconomic factors by using market shares in a model's submarket as the dependent variable instead of unit sales. Doing so indirectly controls for macroeconomic factors that affect all models in a submarket simultaneously. The list includes: changes in aggregate income, changes in motor fuel prices, or changes in tastes that make some submarkets more attractive than others in a given year. For example, the recent increase in the price of gasoline has reduced the demand for larger vehicles relative to smaller ones. However, the gasoline price increase would not affect market shares within a class of similar large cars.

To control for differences in sales resulting from firms' widely different positions of strength within a given submarket because their histories vary, we transform our data into growth rates. Some models have lower unit sales than others in their cohort due to limited distribution 
channels and other unobserved institutional factors. For example, consider the subcompact automobile market in which the buyer could choose between a Suzuki Forenza and a Toyota Corolla. Toyota has a dealer network that is three times the size and, on average, eight times larger than Suzuki (Automotive News 2009).

\subsection{Estimation}

Following Bresnahan (1981), we assume that the distribution of tastes yields a linear demand system. Consequently, we use Ordinary Least Squares to fit a linear model where market share growth is the dependent variable and the list of independent variables include: growth in relative prices, relative advertising, relative quality/reliability with a one year delay, model year length, and number of competitors, as well as, changes in styling, name plate, warranty, safety appliances, and manufacturer incentives. Note, by estimating the model in growth rates, we address the concerns that market shares, prices, and advertising may be highly autocorrelated or even non-stationary due to their slow movement over time.

Since the price of the car enters not only the demand equation but also the supply equation, a natural question is whether price endogeneity is serious enough to bias single equation estimates. We find that a single equation model is appropriate. Neither Hausman nor Wu-Hausman endogeneity tests can reject the null hypothesis of exogenous price. To conduct the tests, for each model year, we take prices of vehicle lines offered by a manufacturer and estimate that component which is common across all lines. While changes in costs generally affect all lines simultaneously, such is rarely the case for changes in demand. Thus, the "common price factor" identifies price changes caused by cost. Then, we instrument price by this common price factor and estimate the model using two-stage instrumental variable regression. The estimates are generally similar to the reported results. Our estimates of the common price factor, instrumental regressions, and Wu-Hausman tests are available upon request. The last line of Tables 2-5 reports the Hausman test statistics. The result is hardly surprising. Most manufacturers produce cars in adjacent market classes and must maintain price differentials between these classes. Also, the costs of manufacturing have been relatively stable over the time period covered (U.S. Department of Labor, 2008). Thus, any supply shocks have been small. 
To summarize, our estimation contributes to the literature by combining in a single model demand determinants that other studies find to be important individually, while adding new determinants, such as vehicle line rebranding. Because many demand determinants often change simultaneously, our model addresses the omitted variable bias to a much greater degree than previous models.

\section{Data Summary}

Table 1 highlights the data. Data sources and definitions are available in the online Appendix. The number of vehicle lines (Panel A) ranges from 131 in the 1996 model year to a 161 in 2004. Registrations vary from a low of 9.7 million, also in 1996, to a high of 12.9 million in 2000. Except for pausing in 2001-2003, nominal median vehicle price inclusive of manufacturer incentives rose from $\$ 19,488$ in 1996, to $\$ 23,180$ in 2006. Except in 1999, domestic market share declined continuously, falling from 69 to 49 percent in our sample. Concurrently, Japanese market share almost doubled to 40 percent, Korean market share increased from 1 to 5 percent, and European market share rose to 7 percent, also almost doubling.

Panel B summarizes the non-price demand determinants. The number of complete restylings ranges from a low 17 in 1996, to highs of 28 in the last two years. Partial restylings ranged from only three lines in 1996, to a high of 25 in 2005. A further examination shows that, on an annual basis, Japanese and Korean manufacturers restyled completely on average 33 percent and 30 percent of their lines, respectively, compared to 24 percent for the 'Detroit 3'.

Warranty improvements and curtailments reflected, for the most part, changes made by Chrysler and VW since the 2000 model year. Quality changes measured by changes in Consumer Union's “reliability index” impacted on average approximately 40 percent of the vehicle lines in a given model year, with 28 percent more downgrades than upgrades over the period.

Manufacturers tended to distribute safety appliance adoptions evenly over the model years, while GM concentrated deletions in 2003, when it deleted previously standard antilock brakes and side airbags on many base models. Rebrandings numbered fewer than ten in every model year except 2006. Finally, advertising expenditures in nominal dollars increased in virtually every model year. 
While multicollinearity is not a problem in our data set, correlations between several of our key variables are high enough that if omitted could cause the omitted variable bias. The correlation between most of our demand determinants is below 10\%. Further, the Belsley, Kuh, and Welsch (1980) collinearity diagnostics do not indicate a potential for multicollinearity. The scaled conditional number, 3.25, is substantially below the 10-30 threshold suggested by them. However, a few of our demand determinants have higher than $10 \%$ correlations. For instance, the correlation coefficient between advertising expenditures and complete restyling is 34\%. The correlations and collinearity diagnostics tables (Tables 4-6) are available in the online Appendix.

\section{Results}

The positive impact of a restyling dominates the other determinants of demand and accounts for the secular decline in domestic market share. A complete restyling on average has a ten times greater impact on market share growth rate than even a 10 percent reduction in relative price. Furthermore, manufacturers would have to double relative advertising expenditures to achieve an effect comparable to a complete restyling. Of changes in warranty, quality, safety, and branding, only rebranding rivals the positive restyling impact. Note that our model fits the data reasonably well, on average explaining over 40 percent of the variation in market share growth.

Tables 2-5 contain estimates of a baseline model. Our dependent variable is the growth rate of the vehicle's market share within its market class. The first column in each table lists the independent variables. The other columns list OLS estimated coefficients for various subsets of the data; the first row indicates the subset's name. Since our dataset includes most vehicle registrations, one can interpret our estimates as the 1995-2006 population averages. We report standard errors in parenthesis and use standard notation to indicate coefficients that are significantly different from zero: under one percent $(* * *)$, five percent $(* *)$, and ten percent $(*)$ significance levels. The last four rows report the number of observations, the adjusted R2, the Durbin-Watson, and the Hausman statistics for each subset.

\subsection{Pooled Results}


Table 2 illustrates the dominant impact of new product, as captured by our styling change variable. It shows the estimates of the coefficients for the entire data set, as well as the car and light truck markets separately. A complete restyling on average yields a 19.78 percent increase in market share growth rate for that model year. Restyling elasticity is positive and statistically significant across all three markets.

The effect of restyling is large if we compare it to price or advertising changes. A 10 percent price decrease (90 percent of relative price decreases were less than that) leads to a 2.1 percent increase in market share growth rate $(-.21 *-10=2.1)$ - one tenth of the restyling effect (19.78). Similarly, manufacturers would have to increase relative advertising share by 100 percent (73 percent of relative advertising increases fell short of that) $(0.15 * 100=15 \%)$ to achieve an effect comparable to a restyling. The size of the complete restyling coefficient suggests that new product introductions (restyling) may provide a better explanation of declining domestic manufacturer market shares than more commonly attributed variables such as product quality.

Restyling has a bigger impact in the car market than in the light truck market, where the base fleet demand is greater. The restyling elasticity for cars, 23.43, is almost twice larger than for trucks, 11.95. Restyling has a multiyear pay back, for a complete restyling has virtually the same impact on own market share growth in the second year, as in the first. In fact, in the light truck market, restyling has a larger impact on market share growth in the second year than it does in the initial year. By the third year, however, the restyling impact on own market share growth has been spent.

To a lesser degree, consumer markets respond favorably to a partial restyling. The market impact of a partial restyling is of a shorter duration, lasting only one model year. In the pooled market, a partial restyling on average yields a 10.71 percent increase in market share growth rate. It is significant at the one percent level. But, in the model year after a partial restyling, the impact virtually evaporates, falling to 0.53 per cent, and ceases to be statistically significant. The results are similar for the cars and trucks subsets.

Warranty term changes showed large and statistically significant impact on market share growth, particularly curtailments. For the pooled market, the decision to curtail one's warranty terms, on average, results in a 24.88 percent decline in one's market share growth, with the coefficient being significant. Given that previous studies, for example Sullivan (1998), find no 
evidence that differences in warranties were a demand determinant, we find it surprising to discover such a large effect.

Unlike warranty curtailments, manufacturers tend to introduce improvements well into the model year. Consequently, the mid-model year enhancements have a lesser impact. For example, Chrysler's warranty enhancements in 2001, 2002, and 2007, were all intra-model year changes.

Consumer Reports quality ratings have little impact on market share growth. What impact we find is in the automobile market, where a one percent increase in the CU quality index results in a 0.07 percent increase in market share growth rate the following model year. We need to interpret this coefficient with care. For example, if the median reliability value for the submarket is three, an improvement in the CU vehicle rating from three to four is equivalent to a 33 percent index increase; thus, market share growth increases by $2.31(0.07 * 33)$ percent. CU's general negativity to light trucks and the demographics of its readership base may explain the complete absence of any Consumer Reports impact in truck markets.

The coefficient of our "safety frontier" appliance variable carried the wrong sign, but was insignificant. Both car and truck vehicle lines that adopted advanced safety appliances actually had declines in market share growth rate. Safety appliance deletions yield a negative, though again, statistically insignificant effect on market share growth in both the automobile and truck submarkets. Virtually every safety appliance deletion emanated from the GM decision to make optional antilock brakes and side airbags on a number of its lines in the early 2000's.

The small and not statistically significant effect of changes in quality and safety are somewhat surprising given the recent media attention to these issues. In recent years, Consumers Union has made its quality rankings readily available to the broader media, for example, USA Today (1996-2008) or NBC Nightly News (2000-2008). With respect to safety, since 1995 the Insurance Institute for Highway Safety, the research and policy promotion arm of the automotive insurance industry has become more visible in the broader media, for example, the NBC news magazine, "Dateline”.

The coefficient of the name change variable is negative and insignificant. However, as we report below, the name change variable is a statistically significant negative determinant of domestic market share. 
Vehicle line advertising expenditures are the most consistent, statistically significant determinant of own market share growth rate. For the pooled data set, a one percent increase in own advertising expenditures, relative to the competitive cohort, yields a 0.15 percent increase in market share growth. The relative advertising elasticity (we use "elasticity” loosely as our left hand side variable is market share growth rate, not quantity) is comparable in both the car and light truck markets.

The relative price elasticity is negative for the pooled and automobile markets. For the pooled data set, a one percent increase in relative price yields a 0.21 percent decline in market share growth. Compared to the pooled market, the car market is more competitive. A one per cent increase in relative price yields a 0.38 percent decline in market share growth rate. Also the car market relative price elasticity is statistically significant. In the truck market, relative price elasticity is positive and not statistically significant. A large portion of truck sales represents fleets. Since ‘corporate’ negotiates prices in these markets, our price variable is less representative. The cash rebate and interest rate subvention coefficients are often negative and statistically insignificant suggesting that incentives do not have additional impact beyond that captured in relative price.

The market structure controls carried the expected signs. Market share growth rate is a positive function of the length of the model year in terms of quarters, and a negative function of the number of competitive vehicles within the submarket.

Finally, we find that keeping the status quo reduces one's market share growth. Status quo implies no change in relative prices, advertising share, and other non-price determinants of demand. When this is the case, the constant in our regression determines average market share growth. A negative, statistically significant constant means that market share growth rate declines if the manufacturer follows a status quo policy.

\subsection{Results by Country of Origin}

Over our observation period, vehicles from American and Japanese based manufacturers represented over 90 percent of vehicle registrations in the U.S. market. Table 3 shows the coefficient estimates when we group the data by country of origin. Columns 2 and 3 show the coefficients for the U.S. and Japan, respectively. 
A complete restyling has a similar impact on market share for both domestic and Japanese manufacturers. For domestic manufacturers a complete restyling yields an 18.21 percent increase in market share growth. For Japanese manufacturers, a complete restyling yields a similar 19.81 percent increase in market share growth. In both markets market share growth rates continues to rise in the year after a complete restyling, with the coefficients remaining significant at the one percent significance level. In the second year of the restyling cycle, market share growth rate for domestic manufacturers increases by 14.54 percent (22.44 percent for Japanese firms).

Restyling alone provides insight as to why domestic market shares have continued their secular decline. While the market share growth rate "bumps" from complete restylings are similar for domestic and Japanese manufacturers, the greater frequency of restyling activity by the latter has a sizable impact on market share trends. To illustrate, we take a simple model where only the constant determines market share growth, as well as current and lagged complete restylings. Note that over the 1995-2006 model years, Japanese manufacturers on average restyled every third year, compared to every four for domestic manufacturers. Using these restyling cycles and our estimates of the constant and the coefficients on current and lagged complete restyling, we can predict market share growth rates from the beginning of our observation period to the present. In 1996 domestic and Japanese market shares were 72.9 and 22.7 percent, respectively. As of January 2009, the domestic market share had declined to 47.5 percent, while the Japanese had risen to 39.5. From restyling alone, our predicted 2008 market shares of 47.9 percent and 39.7 percent virtually coincide with the observed ones. Our results build on those of Kim and Haan (1996), who found that the Japanese dummy was a highly significant market share determinant in the subcompact market over 1982-87.

The partial restyling coefficients are also positive and statistically significant for both domestic and Japanese manufacturers, with the impact for domestic manufacturers being slightly higher. Domestic manufacturers restyle less often; thus, a greater consumer reaction to even a partial restyling. However, in neither market does a partial restyling carry forward to a second year. The shorter impact of a partial restyling is consistent with Millner and Hoffer's (1993) results for an earlier time period.

Over the last 15 years, Korean manufacturers' share of the U.S. market quintupled from 1 percent in 1996 to 5 percent in 2006. Much of the credit for this over five-fold increase has been 
attributed to their restyling activity, lengthened warranty programs, and improved quality. (Consumer Reports, 2004, 50-51). Our estimates confirm this conventional wisdom. Even with relatively few observations for Korea, we find a large and statistically significant effect of a restyling. Market share growth on average increases by 38.88 percent in the year following a restyling. The coefficient is statistically significant at the 5 percent significance level. After adopting a 10 year, 100,000 mile powertrain warranty program, market share growth on average increased by 27.9 percent. Quality improvements on average raised market share growth by 6.5 percent. However, due to few observations neither warranty nor quality changes were statistically significant.

For U.S. and Japanese firms, the coefficient of the CU quality index is close to zero. For European firms, quality improvements on average raised market share growth by 4 percent. The impact is statistically significant. This result reflects CU's readership demographics and the maintenance cost exposure associated with European vehicle lines, given that, except for Volkswagen, they are virtually all luxury or near luxury models.

Compared to others, for U.S. manufacturers, the average effect of a nameplate change is strikingly different. For domestic lines, a rebranding leads to a large and statistically significant decline in market share growth rate. It declines by 22.22 percent, and does not rebound in the subsequent model year as the coefficient of the lagged rebranding variable is small and not statistically significant. American manufacturers may be underestimating the goodwill or brand name capital in their existing nameplates. At a minimum, they are underestimating the efforts needed to launch a new brand. By contrast, for manufacturers from other countries, in a rebranding year market share growth increases by about 20 percent. However, none of the coefficients are statistically significant.

\subsection{Results by Manufacturer}

As Table 4 shows, a complete restyling, particularly lagged a model year is consistently strong across most manufacturers. We have separate columns for each of the six major firms selling light vehicles in the U.S. market. Because of fewer vehicle lines, we combine the smaller Japanese manufacturers and all European manufacturers. 
A partial restyling is most effective for domestic manufacturers. As shown in columns 24, the coefficient of the partial restyling variable is significant for each of the Detroit Three. The partial restyling coefficient is particularly large for Chrysler. On average a partial restyling increases Chrysler's market share growth rate by 36.65 percent. A partial restyling has a stronger impact on Chrysler because its minivan and Jeep vehicle lines tend to have longer restyling cycles, changes being constrained by functionality. With the exception of Toyota, a partial restyling has a lower impact on both Japanese and European firms. We attribute this smaller effect to more subtle exterior changes.

Only two domestic manufacturers, GM and Chrysler, curtailed their warranties over our observation period. Curtailments had a large and negative effect on market shares for both. A warranty curtailment decreased market share growth rate by more than 25 percent for each firm. Interestingly, after 2006, both Chrysler and GM strengthened their warranties likely in response to decreases in market shares reported here. Other results in Table 4 are similar to those in Tables 2 and 3.

\subsection{Results by Market Class}

As Table 5 shows, for every market class except two, near luxury/luxury and minivan, the lagged impact on market share of a complete restyling is stronger than the immediate impact. Hoffer and Milner (1993) report the opposite for automobiles. They found the immediate impact to be stronger than the lagged impact. Production constraints explain the greater carryover effect of a restyling during 1995-2006. Prior to the mid-1990's, manufacturers produced most automobile lines in multiple plants. More recently, few automobile lines have had more than one final assembly plant. The lower production capacity per vehicle line has constrained manufacturer response to the increased demand in the immediate year, carrying over demand to the following year. In the near luxury/luxury and minivan market classes, however, manufacturers could meet within the model year the increased demand generated by a restyling. A single plant producing near luxury/luxury cars has greater excess capacity due to lower volumes, while manufacturers tended to source minivans from multiple plants.

The strongest impact of a favorable $\mathrm{CU}$ recommendation in any submarket examined in this paper occurs in the traditionally-sized car segments. For the large-midsize-compact segment, 
a positive recommendation on average increases market share growth rate by $3.6(.11 * 33)$ percent. For the near luxury-luxury segment a positive recommendation on average increases market share growth by $2.3(.07 * 33)$ percent. Both coefficients are statistically significant. The strong impact reflects that these market classes are disproportionately the choice of more mature individuals, CU's core subscription base. Other results in Table 5 are similar to those in Tables 2, 3 , and 4 .

\section{Discussion}

This paper has extended Pauwels et al. in four directions. First, the time period of the present study more than doubles the model years previously observed, allowing us to study the impact of additional product and non-product innovations. In particular, we show that for domestic manufacturers rebranding and curtailment of long-term powertrain warranties has had a detrimental effect on market shares. Second, after examining the impact of restylings by market class, by manufacturer, and by country of origin, we found that restyling is uniformly the most powerful determinant of market share growth. Third, we incorporate ex-ante measures of consumer perceptions. Generally, consumer perceptions, as measured by the CU "reliability index," impact market share primarily in automotive subclasses where the consumer demographics more closely reflect the demographics of the CU readership base. Fourth, we separated the effects of restylings from increases in advertising expenditures, which on average double with vehicle restylings. Even after controlling for increased advertising expenditures, as well as changes in other demand determinants, restyling remains the most important determinant of market share growth; manufacturers would have to double relative advertising expenditures to match the impact of a restyling.

This paper began by questioning "Why the precipitous decline in domestic market share?” Finding that restyling is the most important demand stimulus, we conclude that domestic manufacturers have been “outproducted.” Over the 1995-2006 model years, Japanese manufacturers on average restyled every third year, compared to every four for domestics. Thus, in only one year of the styling cycle did the average Japanese model not have a styling stimulus, while domestic models on average enjoyed a styling stimulus for only one-half of their 
showroom life. Interestingly, fifty years earlier, Menge (1962) similarly concluded that The Big Three's more frequent restylings drove from the market the Post-War independent American automobile manufacturers (Hudson, Kaiser, Packard, ...).

Why have not the domestic manufacturers restyled their lines more frequently? The increased fragmentation or Balkanization of the domestic automobile market combined with management misallocation of styling resources may provide insight. Since 1960, domestic manufacturers have introduced multiple lines within the same make. Also they have spread restyling budgets uniformly across model lines. Such a policy has limited the resources available for restyling higher volume lines.

To illustrate, consider the 1956-1965 decade. Between 1956 and 1959, Chevrolet had one model-line (excluding on average 7000 Corvettes annually), the standard Chevrolet, producing approximately 1.4 million units annually. By the end of the decade, Chevrolet produced approximately 2.2 million vehicles under four nameplates, with the standard Chevrolet accounting for 1.5 million. In every model-year of that decade, the standard Chevrolet underwent a complete restyling.

Fast forward four decades to 1996-2005, a decade which saw Chevrolet market automobiles under 14 nameplates. Chevrolet restyled its highest volume model-line, the Lumina/Impala, once. The remaining restyling resources went to lower-volume lines. In contrast, over 1996-2005, Toyota restyled its higher-volume lines more frequently than its lowervolume lines. Whereas Chevrolet restyled only one model with an annual volume of at least 100,000 units (Corsica/Malibu) more than once, Toyota restyled every model with the same unit minimum twice. Toyota restyled its lower-volume lines (Tercel/Echo, Celica) only once.

What could the Detroit Three do to halt decline of the market share? The results of our analysis suggest that the domestics' most potent weapon is to increase the level of styling activity, focusing on the higher-volume lines. The recent increase in the pace of styling activity and the pruning of models by domestic manufacturers are moves in the right direction. Importantly, Nakata, Im, Park, and Ha (2006) report that the most important determinant of a successful new product launch is the proficiency of the team charged with that task. Also positive is the post-2006 decision by domestic manufacturers to strengthen their warranty terms. Furthermore, domestic manufacturers should not be so quick to jettison established vehicle line names, as rebranding has an adverse market share impact. Finally, they should devote fewer 
resources to safety appliances, as we find no evidence that being on the "safety frontier" has had a significant sales impact.

\section{References}

Automotive News and Automotive News Automotive Market Data Book. Detroit, MI: Crain; 1995-2008: various issues.

Belsley AD, Kuh E, Welsch RE. Regression diagnostics: Identifying influential data and sources of collinearity. New York: Wiley; 1980.

Berry S, Levinsohn J, Pakes A. (1995) Automobile prices in market equilibrium. Econometrica 1995; 63(4):841-90.

Boulding W, Purohit D. The price of safety. J Consum Res 1996;23:12-25.

Bresnahan TF. Departure from marginal-cost pricing in the American automobile industry. J Econometrics 1981;17: 201-27.

Busse M, Silva-Risso J, Zettelmeyer F. \$1,000 cash back: The pass-through of auto manufacture promotions. Am Econ Rev 2006;96(4):1253-70.

Carbonell P, Rodriguez AI. Designing teams for speedy product development: The moderating effect of technological complexity. J Bus Res 2006; 59:225-32.

Chang DR, Cho H. Organizational memory influences new product success. J Bus Res 2008;61:13-23.

Consumer Reports. Yonkers, NY: Consumers Union of the US; 1995-2008: various issues.

Delre SA, Jager W, Bijmolt THA, Janssen MA. Targeting and timing promotional activities: An agent-based model for the takeoff of new products. J Bus Res 2007;60:826-35.

Hoffer GE, Reilly RJ. Automobile styling as a shift variable: An investigation by firm and by industry. Appl Econ 1984;16 (2):291-99.

Kim O, Haan M. An advertising model for hierarchically structured markets: Application to the automobile industry. J Bus Res 2004;57:829-33.

Kwoka JE. The sales and competitive effects of styling and advertising practices in the U.S. auto industry. Rev Econ Stat 1993;75(4): 649-56.

McCarthy PS. Market price and income elasticities of new vehicle demand. Rev Econ Stat 1996;78(3):543-47. 
Menge JA Style costs change as a market weapon. Q J Econ 1962;76(4):632-47.

Millner EL, Hoffer GE. A reexamination of the impact of automotive styling on demand. Appl Econ 1993;25:101-10.

Nakata C, Im S, Park H, Ha YW Antecedents and consequence of Korean and Japanese new product advantage. J Bus Res 2006;59:28-36.

Pauwels K, Silva-Risso J, Srivasan S, Hanssens DM New products, sales promotions, and firm value: The case of the automobile industry. J Mark 2004;68:142-56.

Purohit D. Exploring the relationship between the markets for new and used durable goods: The case of automobiles. Mark Sci 1992;11(2):154-67.

Pruitt SW, Hoffer GE. Crash test dummies? The impact of televised automotive crash tests on vehicle sales and securities markets. J Public Policy Mark 2004;20(6):102-114.

Reilly R, Hoffer GE. Will retarding the information flow on automobile recalls affect consumer demand? Econ Inq 1983;21(3):444-447.

Sherman R, Hoffer GE. Does automobile style change payoff? Appl Econ 1971;3(3):153-65.

Sullivan MW How brand names affect the demand for twin automobiles. J Mark Res 1998;35:154-65.

Train KE, Winston C. Vehicle choice behavior and the declining market share of U.S. automakers. Int Econ Rev 2007;48(4):1469-96.

U.S. Department of Labor. Average hourly earnings of production workers: Motor vehicle manufacturing. Washington, DC: Bureau of Labor Statistics. 
Table 1: Data Summary

Panel A: Market Description

\begin{tabular}{cccccccc}
\hline Year & $\begin{array}{c}\text { No of } \\
\text { Models }\end{array}$ & $\begin{array}{c}\text { Registration, } \\
\text { mln }\end{array}$ & U.S. & $\begin{array}{c}\text { Mapan } \\
\text { Jant Share } \\
\text { Korea }\end{array}$ & Europe & Price, \$ \\
\hline \hline 1996 & 131 & 9.7 & $69 \%$ & $26 \%$ & $1 \%$ & $4 \%$ & 19,498 \\
1997 & 137 & 11.1 & $69 \%$ & $26 \%$ & $1 \%$ & $4 \%$ & 20,084 \\
1998 & 137 & 10.9 & $67 \%$ & $27 \%$ & $1 \%$ & $4 \%$ & 20,579 \\
1999 & 135 & 11.3 & $68 \%$ & $26 \%$ & $2 \%$ & $5 \%$ & 21,052 \\
2000 & 142 & 12.9 & $63 \%$ & $28 \%$ & $3 \%$ & $6 \%$ & 21,309 \\
2001 & 152 & 12.0 & $60 \%$ & $29 \%$ & $4 \%$ & $7 \%$ & 21,556 \\
2002 & 155 & 12.8 & $60 \%$ & $30 \%$ & $4 \%$ & $6 \%$ & 21,488 \\
2003 & 155 & 12.5 & $57 \%$ & $32 \%$ & $4 \%$ & $6 \%$ & 21,424 \\
2004 & 161 & 12.1 & $55 \%$ & $34 \%$ & $5 \%$ & $6 \%$ & 22,507 \\
2005 & 157 & 11.6 & $54 \%$ & $37 \%$ & $5 \%$ & $4 \%$ & 22,497 \\
2006 & 152 & 10.3 & $49 \%$ & $40 \%$ & $5 \%$ & $7 \%$ & 23,180 \\
\hline \hline
\end{tabular}

Panel B: Non-Price Determinants of Demand

\begin{tabular}{|c|c|c|c|c|c|c|c|c|c|c|}
\hline \multirow[b]{2}{*}{ Year } & \multicolumn{2}{|c|}{ Restylings } & \multicolumn{2}{|c|}{ Warranty } & \multicolumn{2}{|c|}{$\begin{array}{l}\text { CU Rating } \\
\text { Changes }\end{array}$} & \multicolumn{2}{|c|}{$\begin{array}{c}\text { Safety } \\
\text { Appliance }\end{array}$} & \multirow[b]{2}{*}{$\begin{array}{c}\text { Name } \\
\text { Change }\end{array}$} & \multirow{2}{*}{$\begin{array}{l}\text { Adv. } \\
\text { Exp., } \\
\text { \$bln }\end{array}$} \\
\hline & $\begin{array}{l}\text { Cm } \\
\text { plt. }\end{array}$ & $\begin{array}{c}\text { Part } \\
\text { ial }\end{array}$ & $\begin{array}{c}\text { Impr } \\
\text { v. }\end{array}$ & $\begin{array}{c}\text { Curtai } \\
\text { l. }\end{array}$ & Up & Down & Adopt. & Delet. & & \\
\hline 1996 & 17 & 3 & 0 & 0 & 22 & 18 & 15 & 1 & 4 & 4.3 \\
\hline 1997 & 25 & 7 & 0 & 0 & 29 & 17 & 84 & 0 & 3 & 5.2 \\
\hline 1998 & 23 & 16 & 0 & 0 & 14 & 31 & 18 & 0 & 5 & 5.9 \\
\hline 1999 & 22 & 3 & 0 & 0 & 24 & 22 & 8 & 1 & 7 & 5.8 \\
\hline 2000 & 24 & 18 & 7 & 0 & 27 & 32 & 15 & 1 & 5 & 7.0 \\
\hline 2001 & 26 & 24 & 10 & 0 & 20 & 24 & 15 & 0 & 3 & 6.3 \\
\hline 2002 & 22 & 14 & 17 & 0 & 26 & 25 & 13 & 1 & 4 & 6.0 \\
\hline 2003 & 20 & 18 & 23 & 3 & 30 & 44 & 34 & 19 & 6 & 6.8 \\
\hline 2004 & 23 & 24 & 1 & 0 & 41 & 18 & 17 & 2 & 7 & 7.7 \\
\hline 2005 & 28 & 26 & 3 & 0 & 25 & 30 & 25 & 1 & 7 & 7.7 \\
\hline 2006 & 28 & 13 & 14 & 15 & 26 & 35 & 30 & 0 & 10 & 6.0 \\
\hline
\end{tabular}


Table 2: Explaining Market Share Growth: Pooled Results

\begin{tabular}{|c|c|c|c|}
\hline & Pooled & Cars & Trucks \\
\hline Constant & $\begin{array}{c}-9.17^{* * *} \\
(1.58)\end{array}$ & $\begin{array}{c}-9.53 * * * \\
(2.09)\end{array}$ & $\begin{array}{l}-7.2^{* * *} \\
(2.43)\end{array}$ \\
\hline Advertising & $\begin{array}{c}0.15^{* * *} \\
(0.01)\end{array}$ & $\begin{array}{c}0.15^{* * *} \\
(0.01)\end{array}$ & $\begin{array}{c}0.14^{* * * *} \\
(0.02)\end{array}$ \\
\hline Price & $\begin{array}{l}-0.21 \\
(0.15)\end{array}$ & $\begin{array}{l}-0.38^{*} \\
(0.20)\end{array}$ & $\begin{array}{c}0.05 \\
(0.22)\end{array}$ \\
\hline Model Year Length & $\begin{array}{c}0.68 * * * \\
(0.03)\end{array}$ & $\begin{array}{c}0.76^{* * * *} \\
(0.05)\end{array}$ & $\begin{array}{c}0.59 * * * \\
(0.05)\end{array}$ \\
\hline Number of Competitors & $\begin{array}{c}-0.28 * * * \\
(0.07)\end{array}$ & $\begin{array}{c}0.02 \\
(0.12)\end{array}$ & $\begin{array}{c}-0.42 * * * \\
(0.09)\end{array}$ \\
\hline Reliability/Quality & $\begin{array}{c}0.02 \\
(0.02)\end{array}$ & $\begin{array}{c}0.07^{* * *} \\
(0.03)\end{array}$ & $\begin{array}{l}-0.01 \\
(0.02)\end{array}$ \\
\hline Partial Restyling & $\begin{array}{c}10.71 * * * \\
(2.85)\end{array}$ & $\begin{array}{c}10.33^{* * * *} \\
(3.82)\end{array}$ & $\begin{array}{c}11.62 * * * \\
(4.36)\end{array}$ \\
\hline Complete Restyling & $\begin{array}{c}19.78 * * * \\
(3.42)\end{array}$ & $\begin{array}{c}23.43^{* * *} \\
(4.61)\end{array}$ & $\begin{array}{c}11.95 * * \\
(5.07)\end{array}$ \\
\hline Name Change & $\begin{array}{l}-2.30 \\
(6.78)\end{array}$ & $\begin{array}{l}-5.85 \\
(8.88)\end{array}$ & $\begin{array}{c}1.14 \\
(10.53)\end{array}$ \\
\hline Rebates & $\begin{array}{c}-0.74 \\
(1.92)\end{array}$ & $\begin{array}{c}0.38 \\
(2.64)\end{array}$ & $\begin{array}{l}-2.91 \\
(2.82)\end{array}$ \\
\hline Interest Rate Subvention & $\begin{array}{l}-5.16 \\
(3.39)\end{array}$ & $\begin{array}{l}-5.24 \\
(4.29)\end{array}$ & $\begin{array}{l}-4.74 \\
(5.62)\end{array}$ \\
\hline $\begin{array}{l}\text { Safety Appliance } \\
\text { Adoption }\end{array}$ & $\begin{array}{l}-4.95 \\
(4.37)\end{array}$ & $\begin{array}{l}-2.17 \\
(5.07)\end{array}$ & $\begin{array}{l}-13.25 \\
(9.92)\end{array}$ \\
\hline Safety Appliance Deletion & $\begin{array}{l}-7.64 \\
(6.53)\end{array}$ & $\begin{array}{l}-12.22 \\
(8.57)\end{array}$ & $\begin{array}{c}-0.57 \\
(10.06)\end{array}$ \\
\hline Warranty Improvement & $\begin{array}{c}3.25 \\
(3.88)\end{array}$ & $\begin{array}{c}3.48 \\
(5.45)\end{array}$ & $\begin{array}{c}2.62 \\
(5.37)\end{array}$ \\
\hline Warranty Curtailment & $\begin{array}{c}-24.88^{* * * *} \\
(8.12)\end{array}$ & $\begin{array}{c}-34.96^{* *} \\
(18.14)\end{array}$ & $\begin{array}{c}-21.48^{* * *} \\
(8.66)\end{array}$ \\
\hline Lagged Partial Restyling & $\begin{array}{c}0.53 \\
(2.79)\end{array}$ & $\begin{array}{l}-1.19 \\
(3.75)\end{array}$ & $\begin{array}{c}2.79 \\
(4.14)\end{array}$ \\
\hline $\begin{array}{l}\text { Lagged Complete } \\
\text { Restyling }\end{array}$ & $\begin{array}{c}19.91^{* * *} \\
(2.81)\end{array}$ & $\begin{array}{c}20.47^{* * * *} \\
(3.73)\end{array}$ & $\begin{array}{c}18.95^{* * * *} \\
(4.25)\end{array}$ \\
\hline Lagged Name Change & $\begin{array}{l}-5.21 \\
(5.09)\end{array}$ & $\begin{array}{l}-4.92 \\
(6.68)\end{array}$ & $\begin{array}{l}-7.81 \\
(7.92)\end{array}$ \\
\hline $\mathbf{N}$ & 1214 & 717 & 497 \\
\hline R2adj & $42 \%$ & $45 \%$ & $38 \%$ \\
\hline DI & 2.26 & 2.21 & 2.26 \\
\hline Hausman & 0.30 & 0.14 & 0.58 \\
\hline
\end{tabular}


Table 3: Explaining Market Share Growth: Countries

\begin{tabular}{|c|c|c|c|c|}
\hline & \multicolumn{4}{|c|}{ Country } \\
\hline & USA & Japan & Korea & Europe \\
\hline Constant & $\begin{array}{c}-11.27 * * * \\
(2.37)\end{array}$ & $\begin{array}{c}-8.81 * * * \\
(2.70)\end{array}$ & $\begin{array}{c}-8.60 \\
(13.74)\end{array}$ & $\begin{array}{l}-5.55 \\
(4.05)\end{array}$ \\
\hline Advertising & $\begin{array}{c}0.19 * * * \\
(0.02)\end{array}$ & $\begin{array}{c}0.13^{* * *} \\
(0.02)\end{array}$ & $\begin{array}{c}0.19 * * * \\
(0.06)\end{array}$ & $\begin{array}{c}0.09 * * * \\
(0.03)\end{array}$ \\
\hline Price & $\begin{array}{l}-0.12 \\
(0.19)\end{array}$ & $\begin{array}{l}-0.5^{*} \\
(0.29)\end{array}$ & $\begin{array}{c}0.90 \\
(0.97)\end{array}$ & $\begin{array}{c}0.02 \\
(0.47)\end{array}$ \\
\hline Model Year Length & $\begin{array}{c}0.61 * * * \\
(0.04)\end{array}$ & $\begin{array}{c}0.67 * * * \\
(0.07)\end{array}$ & $\begin{array}{c}0.72 * * * \\
(0.19)\end{array}$ & $\begin{array}{c}0.92 * * * \\
(0.10)\end{array}$ \\
\hline Number of Competitors & $\begin{array}{l}-0.2 * * \\
(0.10)\end{array}$ & $\begin{array}{c}-0.38 * * * \\
(0.12)\end{array}$ & $\begin{array}{l}-0.33 \\
(0.46)\end{array}$ & $\begin{array}{l}-0.02 \\
(0.25)\end{array}$ \\
\hline Reliability/Quality & $\begin{array}{c}0.00 \\
(0.02)\end{array}$ & $\begin{array}{c}0.04 \\
(0.07)\end{array}$ & $\begin{array}{c}0.13 \\
(0.10)\end{array}$ & $\begin{array}{l}0.12 * * \\
(0.05)\end{array}$ \\
\hline Partial Restyling & $\begin{array}{c}15.31 * * * \\
(3.96)\end{array}$ & $\begin{array}{c}10.47 * * \\
(5.00)\end{array}$ & $\begin{array}{c}-1.87 \\
(15.02)\end{array}$ & $\begin{array}{c}8.90 \\
(9.06)\end{array}$ \\
\hline Complete Restyling & $\begin{array}{c}18.21^{* * *} \\
(4.91)\end{array}$ & $\begin{array}{c}19.81^{* * *} \\
(6.27)\end{array}$ & $\begin{array}{c}-3.03 \\
(17.49)\end{array}$ & $\begin{array}{c}33.86 * * * \\
(9.33)\end{array}$ \\
\hline Name Change & $\begin{array}{c}-23.68 * * * \\
(8.84)\end{array}$ & $\begin{array}{c}17.11 \\
(13.42)\end{array}$ & - & $\begin{array}{c}19.83 \\
(17.84)\end{array}$ \\
\hline Rebates & $\begin{array}{c}2.08 \\
(2.61)\end{array}$ & $\begin{array}{l}-4.54 \\
(4.25)\end{array}$ & $\begin{array}{c}8.44 \\
(13.75)\end{array}$ & $\begin{array}{l}-4.60 \\
(7.42)\end{array}$ \\
\hline Interest Rate Subvention & $\begin{array}{c}0.03 \\
(5.52)\end{array}$ & $\begin{array}{l}-6.58 \\
(6.32)\end{array}$ & $\begin{array}{c}-7.38 \\
(18.58)\end{array}$ & $\begin{array}{c}-11.33^{*} \\
(6.74)\end{array}$ \\
\hline $\begin{array}{l}\text { Safety Appliance } \\
\text { Adoption }\end{array}$ & $\begin{array}{l}-5.11 \\
(8.85)\end{array}$ & $\begin{array}{l}-7.25 \\
(7.57)\end{array}$ & - & $\begin{array}{c}0.63 \\
(7.55)\end{array}$ \\
\hline $\begin{array}{l}\text { Safety Appliance } \\
\text { Deletion }\end{array}$ & $\begin{array}{l}-6.61 \\
(6.18)\end{array}$ & $\begin{array}{l}-16.24 \\
(32.64)\end{array}$ & - & - \\
\hline Warranty Improvement & $\begin{array}{l}-0.95 \\
(4.81)\end{array}$ & $\begin{array}{c}2.08 \\
(7.92)\end{array}$ & $\begin{array}{c}27.90 \\
(20.23)\end{array}$ & $\begin{array}{c}7.49 \\
(13.93)\end{array}$ \\
\hline Warranty Curtailment & $\begin{array}{c}-20.06 * * * \\
(8.06)\end{array}$ & $\begin{array}{c}-52.94 * * \\
(24.04)\end{array}$ & - & - \\
\hline Lagged Partial Restyling & $\begin{array}{c}3.63 \\
(3.87)\end{array}$ & $\begin{array}{c}3.40 \\
(4.93)\end{array}$ & $\begin{array}{l}-10.73 \\
(15.19)\end{array}$ & $\begin{array}{c}-15.02^{*} \\
(8.50)\end{array}$ \\
\hline $\begin{array}{l}\text { Lagged Complete } \\
\text { Restyling }\end{array}$ & $\begin{array}{c}14.54 * * * \\
(3.82)\end{array}$ & $\begin{array}{c}22.44 * * * \\
(5.09)\end{array}$ & $\begin{array}{l}38.88 * * \\
(18.00)\end{array}$ & $\begin{array}{c}21.51^{* * *} \\
(7.71)\end{array}$ \\
\hline Lagged Name Change & $\begin{array}{c}5.55 \\
(6.35)\end{array}$ & $\begin{array}{l}-14.29 \\
(10.39)\end{array}$ & - & $\begin{array}{l}-20.69 \\
(13.30)\end{array}$ \\
\hline $\mathbf{N}$ & 622 & 395 & 54 & 143 \\
\hline R2adj & $44 \%$ & $35 \%$ & $44 \%$ & $56 \%$ \\
\hline DW & 2.36 & 2.16 & 1.96 & 2.10 \\
\hline Hausman & 1.45 & 1.28 & $2.72 *$ & 1.08 \\
\hline
\end{tabular}


Table 4: Explaining Market Share Growth: Manufacturer

\section{Make}

\begin{tabular}{|c|c|c|c|c|c|c|c|c|}
\hline & GM & Ford & Chrysler & Toyota & Honda & Nissan & SmlJap & Europe \\
\hline Constant & $\begin{array}{c}-12.18 * * * \\
(2.92)\end{array}$ & $\begin{array}{c}-16.42 * * * \\
(5.81)\end{array}$ & $\begin{array}{l}-4.82 \\
(5.31)\end{array}$ & $\begin{array}{c}-11.08 * * \\
(4.72)\end{array}$ & $\begin{array}{l}-6.21 \\
(5.21)\end{array}$ & $\begin{array}{c}-12.53 * * \\
(5.78)\end{array}$ & $\begin{array}{c}0.60 \\
(7.17)\end{array}$ & $\begin{array}{l}-5.55 \\
(4.05)\end{array}$ \\
\hline Advertising & $\begin{array}{l}0.19 * * * \\
(0.02)\end{array}$ & $\begin{array}{c}0.16^{* * *} \\
(0.03)\end{array}$ & $\begin{array}{c}0.23 * * * \\
(0.04)\end{array}$ & $\begin{array}{c}0.25 * * * \\
(0.05)\end{array}$ & $\begin{array}{c}0.04 \\
(0.06)\end{array}$ & $\begin{array}{l}0.08 * \\
(0.04)\end{array}$ & $\begin{array}{l}0.11^{* *} \\
(0.05)\end{array}$ & $\begin{array}{c}0.09 * * * \\
(0.03)\end{array}$ \\
\hline Price & $\begin{array}{l}-0.13 \\
(0.25)\end{array}$ & $\begin{array}{l}-0.54 \\
(0.42)\end{array}$ & $\begin{array}{c}0.48 \\
(0.48)\end{array}$ & $\begin{array}{c}0.58 \\
(0.66)\end{array}$ & $\begin{array}{l}-0.95 \\
(0.76)\end{array}$ & $\begin{array}{l}-0.80 \\
(0.58)\end{array}$ & $\begin{array}{l}-0.69 \\
(0.66)\end{array}$ & $\begin{array}{c}0.02 \\
(0.47)\end{array}$ \\
\hline $\begin{array}{l}\text { Model Year } \\
\text { Length }\end{array}$ & $\begin{array}{l}0.5^{* * *} \\
(0.05)\end{array}$ & $\begin{array}{c}0.62 * * * \\
(0.09)\end{array}$ & $\begin{array}{c}0.82 * * * \\
(0.11)\end{array}$ & $\begin{array}{c}0.77 * * * \\
(0.15)\end{array}$ & $\begin{array}{c}0.54 * * * \\
(0.17)\end{array}$ & $\begin{array}{c}1.02 * * * \\
(0.15)\end{array}$ & $\begin{array}{c}0.54^{* * * *} \\
(0.20)\end{array}$ & $\begin{array}{l}0.92^{* * *} \\
(0.10)\end{array}$ \\
\hline $\begin{array}{l}\text { Number of } \\
\text { Competitors }\end{array}$ & $\begin{array}{l}-0.11 \\
(0.15)\end{array}$ & $\begin{array}{l}-0.14 \\
(0.21)\end{array}$ & $\begin{array}{c}-0.51^{* * * *} \\
(0.20)\end{array}$ & $\begin{array}{l}-0.24 \\
(0.19)\end{array}$ & $\begin{array}{c}-0.8 * * * \\
(0.25)\end{array}$ & $\begin{array}{c}0.10 \\
(0.41)\end{array}$ & $\begin{array}{l}-0.06 \\
(0.25)\end{array}$ & $\begin{array}{l}-0.02 \\
(0.25)\end{array}$ \\
\hline $\begin{array}{l}\text { Reliability/Quali } \\
\text { ty }\end{array}$ & $\begin{array}{c}0.00 \\
(0.02)\end{array}$ & $\begin{array}{l}-0.02 \\
(0.05)\end{array}$ & $\begin{array}{c}0.00 \\
(0.04)\end{array}$ & $\begin{array}{l}-0.15 \\
(0.14)\end{array}$ & $\begin{array}{c}0.09 \\
(0.25)\end{array}$ & $\begin{array}{c}0.31 \\
(0.28)\end{array}$ & $\begin{array}{c}0.10 \\
(0.15)\end{array}$ & $\begin{array}{l}0.12 * * \\
(0.05)\end{array}$ \\
\hline Partial Restyling & $\begin{array}{l}9.29 * \\
(5.51)\end{array}$ & $\begin{array}{l}24.78 * * * \\
(6.72)\end{array}$ & $\begin{array}{c}36.93 * * * \\
(10.39)\end{array}$ & $\begin{array}{l}16.36 * \\
(8.65)\end{array}$ & $\begin{array}{c}9.83 \\
(13.31)\end{array}$ & $\begin{array}{c}18.59 \\
(12.32)\end{array}$ & $\begin{array}{c}-1.21 \\
(10.52)\end{array}$ & $\begin{array}{c}8.90 \\
(9.06)\end{array}$ \\
\hline $\begin{array}{l}\text { Complete } \\
\text { Restyling }\end{array}$ & $\begin{array}{l}12.21 * \\
(7.17)\end{array}$ & $\begin{array}{c}31.13^{* * *} \\
(10.30)\end{array}$ & $\begin{array}{c}4.74 \\
(9.39)\end{array}$ & $\begin{array}{c}14.83 \\
(11.76)\end{array}$ & $\begin{array}{c}34.88 * * * \\
(10.75)\end{array}$ & $\begin{array}{c}8.56 \\
(15.14)\end{array}$ & $\begin{array}{l}36.18 * \\
(20.22)\end{array}$ & $\begin{array}{c}33.86 * * * \\
(9.33)\end{array}$ \\
\hline Name Change & $\begin{array}{l}-15.90 \\
(11.27)\end{array}$ & $\begin{array}{c}-40.64 * * \\
(19.35)\end{array}$ & $\begin{array}{c}34.34 \\
(28.86)\end{array}$ & - & $\begin{array}{l}-39.82 \\
(36.35)\end{array}$ & $\begin{array}{c}8.87 \\
(27.65)\end{array}$ & $\begin{array}{c}28.20 \\
(29.86)\end{array}$ & $\begin{array}{c}19.83 \\
(17.84)\end{array}$ \\
\hline Rebates & $\begin{array}{c}4.35 \\
(3.38)\end{array}$ & $\begin{array}{l}-1.18 \\
(6.20)\end{array}$ & $\begin{array}{l}-2.16 \\
(5.87)\end{array}$ & $\begin{array}{c}1.70 \\
(7.14)\end{array}$ & $\begin{array}{c}0.24 \\
(14.64)\end{array}$ & $\begin{array}{c}8.21 \\
(10.63)\end{array}$ & $\begin{array}{l}-15.84 \\
(10.07)\end{array}$ & $\begin{array}{l}-4.60 \\
(7.42)\end{array}$ \\
\hline $\begin{array}{l}\text { Interest Rate } \\
\text { Subvention }\end{array}$ & $\begin{array}{l}-7.11 \\
(7.26)\end{array}$ & $\begin{array}{l}20.66 * * \\
(10.08)\end{array}$ & $\begin{array}{c}4.34 \\
(19.24)\end{array}$ & $\begin{array}{c}-5.71 \\
(14.88)\end{array}$ & $\begin{array}{c}-3.39 \\
(22.68)\end{array}$ & $\begin{array}{c}-4.89 \\
(12.30)\end{array}$ & $\begin{array}{l}-14.54 \\
(11.68)\end{array}$ & $\begin{array}{l}-11.33^{*} \\
(6.74)\end{array}$ \\
\hline $\begin{array}{l}\text { Safety Appliance } \\
\text { Adoption }\end{array}$ & $\begin{array}{c}0.67 \\
(10.38)\end{array}$ & $\begin{array}{l}-47.5^{*} \\
(27.26)\end{array}$ & $\begin{array}{l}-30.03 \\
(28.49)\end{array}$ & $\begin{array}{c}-20.32 * * \\
(9.99)\end{array}$ & $\begin{array}{l}-38.54 * \\
(19.78)\end{array}$ & $\begin{array}{c}7.30 \\
(19.05)\end{array}$ & $\begin{array}{c}16.12 \\
(21.77)\end{array}$ & $\begin{array}{c}0.63 \\
(7.55)\end{array}$ \\
\hline $\begin{array}{l}\text { Safety Appliance } \\
\text { Deletion }\end{array}$ & $\begin{array}{l}-10.56 \\
(6.83)\end{array}$ & $\begin{array}{c}39.67 \\
(27.37)\end{array}$ & $\begin{array}{c}34.59 \\
(28.88)\end{array}$ & $\begin{array}{l}-20.27 \\
(29.87)\end{array}$ & - & - & - & - \\
\hline $\begin{array}{l}\text { Warranty } \\
\text { Improvement }\end{array}$ & $\begin{array}{c}1.82 \\
(10.16)\end{array}$ & $\begin{array}{c}21.44 \\
(25.98)\end{array}$ & $\begin{array}{l}-6.34 \\
(6.37)\end{array}$ & - & $\begin{array}{c}-1.20 \\
(11.11)\end{array}$ & - & $\begin{array}{c}3.49 \\
(14.80)\end{array}$ & $\begin{array}{c}7.49 \\
(13.93)\end{array}$ \\
\hline $\begin{array}{l}\text { Warranty } \\
\text { Curtailment }\end{array}$ & $\begin{array}{l}-25.24 \\
(20.56)\end{array}$ & - & $\begin{array}{l}-26 * * * \\
(8.62)\end{array}$ & - & - & - & - & - \\
\hline $\begin{array}{l}\text { Lagged Partial } \\
\text { Restyling }\end{array}$ & $\begin{array}{l}2.56 \\
(5.52)\end{array}$ & $\begin{array}{l}10.97 * \\
(6.29)\end{array}$ & $\begin{array}{c}0.54 \\
(9.55)\end{array}$ & $\begin{array}{l}11.21 \\
(8.06)\end{array}$ & $\begin{array}{c}10.93 \\
(13.07)\end{array}$ & $\begin{array}{c}-3.59 \\
(12.33)\end{array}$ & $\begin{array}{c}-4.78 \\
(10.54)\end{array}$ & $\begin{array}{c}-15.02 * \\
(8.50)\end{array}$ \\
\hline $\begin{array}{l}\text { Lagged } \\
\text { Complete }\end{array}$ & $17.68 * * *$ & $13.95 *$ & $21.8 * * *$ & $31.15^{* * *}$ & $20.08 * *$ & 17.03 & 2.68 & $21.51^{* * *}$ \\
\hline Restyling & (5.35) & $(7.70)$ & $(7.40)$ & (7.94) & (10.23) & (10.96) & $(16.10)$ & (7.71) \\
\hline $\begin{array}{l}\text { Lagged Name } \\
\text { Change }\end{array}$ & $\begin{array}{l}11.68 \\
(8.08)\end{array}$ & $\begin{array}{l}-28.04^{*} \\
(16.14)\end{array}$ & $\begin{array}{c}0.10 \\
(14.65)\end{array}$ & $\begin{array}{c}-9.66 \\
(21.47)\end{array}$ & $\begin{array}{l}-28.87 \\
(23.05)\end{array}$ & $\begin{array}{l}-18.38 \\
(21.10)\end{array}$ & $\begin{array}{c}1.91 \\
(22.01)\end{array}$ & $\begin{array}{l}-20.69 \\
(13.30)\end{array}$ \\
\hline $\mathbf{N}$ & 375 & 139 & 133 & 112 & 82 & 81 & 95 & 143 \\
\hline R2adj & $36 \%$ & $52 \%$ & $59 \%$ & $47 \%$ & $31 \%$ & $47 \%$ & $28 \%$ & $56 \%$ \\
\hline DW & 2.44 & 1.86 & 2.45 & 1.74 & 2.24 & 1.86 & 2.25 & 2.10 \\
\hline Hausman & 0.43 & 0.74 & 0.57 & 1.97 & 0.23 & 0.00 & 0.22 & 0.35 \\
\hline
\end{tabular}


Table 5: Explaining Market Share Growth: Subclasses

\begin{tabular}{|c|c|c|c|c|c|c|}
\hline & \multicolumn{6}{|c|}{ Large Subclasses } \\
\hline & $\begin{array}{c}\text { Luxury/ Near } \\
\text { Luxury }\end{array}$ & $\begin{array}{c}\text { Large/Midsiz } \\
\text { e/Compact }\end{array}$ & $\begin{array}{c}\text { Sub } \\
\text { Compact }\end{array}$ & $\begin{array}{c}\text { Large } \\
\text { SUV/Trucks }\end{array}$ & $\begin{array}{l}\text { Other } \\
\text { SUV }\end{array}$ & Minivan \\
\hline Constant & $\begin{array}{c}-12.09 * * * \\
(2.79)\end{array}$ & $\begin{array}{l}-3.53 \\
(4.05)\end{array}$ & $\begin{array}{l}-7.39 \\
(5.22)\end{array}$ & $\begin{array}{l}-6.04 \\
(4.78)\end{array}$ & $\begin{array}{l}-5.43^{*} \\
(3.12)\end{array}$ & $\begin{array}{l}-2.74 \\
(5.71)\end{array}$ \\
\hline Advertising & $\begin{array}{c}0.09 * * * \\
(0.02)\end{array}$ & $\begin{array}{c}0.24 * * * \\
(0.03)\end{array}$ & $\begin{array}{c}0.17^{* * * *} \\
(0.04)\end{array}$ & $\begin{array}{l}0.06 * \\
(0.03)\end{array}$ & $\begin{array}{l}0.2 * * * \\
(0.02)\end{array}$ & $\begin{array}{c}0.13 * * * \\
(0.04)\end{array}$ \\
\hline Price & $\begin{array}{l}-0.52 * \\
(0.32)\end{array}$ & $\begin{array}{l}-0.33 \\
(0.37)\end{array}$ & $\begin{array}{l}-0.55 \\
(0.41)\end{array}$ & $\begin{array}{c}0.45 \\
(0.33)\end{array}$ & $\begin{array}{l}-0.15 \\
(0.36)\end{array}$ & $\begin{array}{l}-0.34 \\
(0.49)\end{array}$ \\
\hline Model Year Length & $\begin{array}{c}0.82 * * * \\
(0.07)\end{array}$ & $\begin{array}{c}0.67 * * * \\
(0.08)\end{array}$ & $\begin{array}{c}0.71^{* * *} \\
(0.11)\end{array}$ & $\begin{array}{c}0.71^{* * *} \\
(0.08)\end{array}$ & $\begin{array}{c}0.63 * * * \\
(0.07)\end{array}$ & $\begin{array}{c}0.37 * * * \\
(0.12)\end{array}$ \\
\hline $\begin{array}{l}\text { Number of } \\
\text { Competitors }\end{array}$ & $\begin{array}{c}0.01 \\
(0.19)\end{array}$ & $\begin{array}{c}0.18 \\
(0.24)\end{array}$ & $\begin{array}{l}-0.08 \\
(0.24)\end{array}$ & $\begin{array}{c}-0.54 * * \\
(0.22)\end{array}$ & $\begin{array}{c}-0.59 * * * \\
(0.10)\end{array}$ & $\begin{array}{c}0.31 \\
(0.23)\end{array}$ \\
\hline Reliability/Quality & $\begin{array}{l}0.07 * \\
(0.04)\end{array}$ & $\begin{array}{c}0.11^{* * *} \\
(0.04)\end{array}$ & $\begin{array}{c}0.05 \\
(0.06)\end{array}$ & $\begin{array}{l}-0.01 \\
(0.03)\end{array}$ & $\begin{array}{l}-0.03 \\
(0.03)\end{array}$ & $\begin{array}{l}-0.09 \\
(0.09)\end{array}$ \\
\hline Partial Restyling & $\begin{array}{c}13.88 * * \\
(6.31)\end{array}$ & $\begin{array}{c}14.49 * * * \\
(5.82)\end{array}$ & $\begin{array}{l}-2.03 \\
(8.58)\end{array}$ & $\begin{array}{c}5.86 \\
(8.81)\end{array}$ & $\begin{array}{c}6.40 \\
(5.19)\end{array}$ & $\begin{array}{l}20.95^{*} \\
(11.64)\end{array}$ \\
\hline Complete Restyling & $\begin{array}{c}36.69 * * * \\
(7.54)\end{array}$ & $\begin{array}{c}8.85 \\
(7.87)\end{array}$ & $\begin{array}{l}16.92 * \\
(9.49)\end{array}$ & $\begin{array}{l}12.01 \\
(8.60)\end{array}$ & $\begin{array}{c}7.37 \\
(7.44)\end{array}$ & $\begin{array}{c}18.13 \\
(12.13)\end{array}$ \\
\hline Name Change & $\begin{array}{c}7.98 \\
(13.36)\end{array}$ & $\begin{array}{c}-30.18^{* *} \\
(15.61)\end{array}$ & $\begin{array}{l}-20.67 \\
(19.45)\end{array}$ & $\begin{array}{l}-39.86 \\
(28.40)\end{array}$ & $\begin{array}{c}7.29 \\
(13.04)\end{array}$ & $\begin{array}{c}10.86 \\
(22.56)\end{array}$ \\
\hline Rebates & $\begin{array}{l}-3.04 \\
(5.23)\end{array}$ & $\begin{array}{l}-5.93 \\
(4.37)\end{array}$ & $\begin{array}{c}4.82 \\
(6.00)\end{array}$ & $\begin{array}{c}4.14 \\
(5.33)\end{array}$ & $\begin{array}{l}-5.41 \\
(3.69)\end{array}$ & $\begin{array}{c}-15.23 * * \\
(6.44)\end{array}$ \\
\hline $\begin{array}{l}\text { Interest Rate } \\
\text { Subvention }\end{array}$ & $\begin{array}{c}-10.66^{*} \\
(6.29)\end{array}$ & $\begin{array}{l}-9.63 \\
(7.41)\end{array}$ & $\begin{array}{l}13.52 \\
(9.81)\end{array}$ & $\begin{array}{l}-18.78 * \\
(10.40)\end{array}$ & $\begin{array}{c}0.76 \\
(6.31)\end{array}$ & $\begin{array}{c}-9.68 \\
(23.21)\end{array}$ \\
\hline $\begin{array}{l}\text { Safety Appliance } \\
\text { Adoption }\end{array}$ & $\begin{array}{l}-1.62 \\
(5.84)\end{array}$ & $\begin{array}{c}3.82 \\
(15.33)\end{array}$ & $\begin{array}{c}18.33 \\
(19.98)\end{array}$ & - & $\begin{array}{c}-8.01 \\
(11.64)\end{array}$ & $\begin{array}{l}-13.36 \\
(18.35)\end{array}$ \\
\hline $\begin{array}{l}\text { Safety Appliance } \\
\text { Deletion }\end{array}$ & - & $\begin{array}{l}-3.62 \\
(9.37)\end{array}$ & $\begin{array}{l}-38.17^{*} \\
(21.24)\end{array}$ & $\begin{array}{l}-15.88 \\
(19.87)\end{array}$ & $\begin{array}{l}-28.65 \\
(24.68)\end{array}$ & $\begin{array}{c}21.52 \\
(14.62)\end{array}$ \\
\hline $\begin{array}{l}\text { Warranty } \\
\text { Improvement }\end{array}$ & $\begin{array}{c}1.89 \\
(9.90)\end{array}$ & $\begin{array}{c}4.73 \\
(8.11)\end{array}$ & $\begin{array}{c}-2.04 \\
(11.69)\end{array}$ & $\begin{array}{c}1.73 \\
(11.73)\end{array}$ & $\begin{array}{l}-0.96 \\
(6.57)\end{array}$ & $\begin{array}{c}18.99 \\
(12.64)\end{array}$ \\
\hline $\begin{array}{l}\text { Warranty } \\
\text { Curtailment }\end{array}$ & - & $\begin{array}{l}-32.58 * \\
(17.67)\end{array}$ & - & $\begin{array}{l}-20.42 \\
(19.89)\end{array}$ & $\begin{array}{c}-25.34 * * * \\
(9.42)\end{array}$ & $\begin{array}{c}36.77 \\
(27.44)\end{array}$ \\
\hline $\begin{array}{l}\text { Lagged Partial } \\
\text { Restyling }\end{array}$ & $\begin{array}{l}-3.54 \\
(6.13)\end{array}$ & $\begin{array}{c}0.16 \\
(5.60)\end{array}$ & $\begin{array}{c}0.89 \\
(8.73)\end{array}$ & $\begin{array}{c}8.40 \\
(9.16)\end{array}$ & $\begin{array}{c}3.87 \\
(4.93)\end{array}$ & $\begin{array}{c}-9.55 \\
(10.52)\end{array}$ \\
\hline $\begin{array}{l}\text { Lagged Complete } \\
\text { Restyling } \\
\text { Lagged Name Change }\end{array}$ & $\begin{array}{c}14.4^{* * *} \\
(5.84) \\
-8.62 \\
(9.63)\end{array}$ & $\begin{array}{c}16.93^{* * *} \\
(6.19) \\
10.17 \\
(11.24) \\
\end{array}$ & $\begin{array}{c}26.9 * * * \\
(8.01) \\
-20.87 \\
(16.88)\end{array}$ & $\begin{array}{c}20.85^{* * *} \\
(7.70) \\
4.50 \\
(16.42)\end{array}$ & $\begin{array}{c}12.31 * * \\
(5.99) \\
2.39 \\
(12.37)\end{array}$ & $\begin{array}{c}13.65 \\
(9.97) \\
-4.50 \\
(14.96)\end{array}$ \\
\hline $\mathbf{N}$ & 278 & 276 & 163 & 166 & 208 & 123 \\
\hline R2adj & $45 \%$ & $50 \%$ & $42 \%$ & $38 \%$ & $56 \%$ & $25 \%$ \\
\hline DW & 2.14 & 2.33 & 2.08 & 2.21 & 2.29 & 2.32 \\
\hline Hausman & 0.71 & 0.24 & 0.35 & 0.83 & 0.23 & 0.08 \\
\hline
\end{tabular}

